\title{
Spatial variability of the direct radiative forcing of biomass burning aerosols and the effects of land use change in Amazonia
}

\author{
E. T. Sena, P. Artaxo, and A. L. Correia \\ Institute of Physics, University of São Paulo, São Paulo, Brazil \\ Correspondence to: E. T. Sena (elisats@if.usp.br) \\ Received: 30 May 2012 - Published in Atmos. Chem. Phys. Discuss.: 12 June 2012 \\ Revised: 13 December 2012 - Accepted: 4 January 2013 - Published: 1 February 2013
}

\begin{abstract}
This paper addresses the Amazonian shortwave radiative budget over cloud-free conditions after considering three aspects of deforestation: (i) the emission of aerosols from biomass burning due to forest fires; (ii) changes in surface albedo after deforestation; and (iii) modifications in the column water vapour amount over deforested areas. Simultaneous Clouds and the Earth's Radiant Energy System (CERES) shortwave fluxes and aerosol optical depth (AOD) retrievals from the Moderate Resolution Imaging SpectroRadiometer (MODIS) were analysed during the peak of the biomass burning seasons (August and September) from 2000 to 2009. A discrete-ordinate radiative transfer (DISORT) code was used to extend instantaneous remote sensing radiative forcing assessments into 24-h averages.

The mean direct radiative forcing of aerosols at the top of the atmosphere (TOA) during the biomass burning season for the $10-\mathrm{yr}$ studied period was $-5.6 \pm 1.7 \mathrm{~W} \mathrm{~m}^{-2}$. Furthermore, the spatial distribution of the direct radiative forcing of aerosols over Amazonia was obtained for the biomass burning season of each year. It was observed that for high AOD (larger than 1 at $550 \mathrm{~nm}$ ) the maximum daily direct aerosol radiative forcing at the TOA may be as high as $-20 \mathrm{~W} \mathrm{~m}^{-2}$ locally. The surface reflectance plays a major role in the aerosol direct radiative effect. The study of the effects of biomass burning aerosols over different surface types shows that the direct radiative forcing is systematically more negative over forest than over savannah-like covered areas. Values of $-15.7 \pm 2.4 \mathrm{~W} \mathrm{~m}^{-2} / \tau_{550 \mathrm{~nm}}$ and $-9.3 \pm 1.7 \mathrm{~W} \mathrm{~m}^{-2} / \tau_{550 \mathrm{~nm}}$ were calculated for the mean daily aerosol forcing efficiencies over forest and savannah-like vegetation respectively. The overall mean annual land use change radiative forcing due to deforestation over the state of Rondônia, Brazil, was
\end{abstract}

determined as $-7.3 \pm 0.9 \mathrm{~W} \mathrm{~m}^{-2}$. Biomass burning aerosols impact the radiative budget for approximately two months per year, whereas the surface albedo impact is observed throughout the year. Because of this difference, the estimated impact in the Amazonian annual radiative budget due to surface albedo-change is approximately 6 times higher than the impact due to aerosol emissions. The influence of atmospheric water vapour content in the radiative budget was also studied using AERONET column water vapour. It was observed that column water vapour is on average smaller by about $0.35 \mathrm{~cm}$ (around $10 \%$ of the total column water vapour) over deforested areas compared to forested areas. Our results indicate that this drying contributes to an increase in the shortwave radiative forcing, which varies from $0.4 \mathrm{~W} \mathrm{~m}^{-2}$ to $1.2 \mathrm{~W} \mathrm{~m}^{-2}$ depending on the column water vapour content before deforestation.

The large radiative forcing values presented in this study point out that deforestation could have strong implications in convection, cloud development and the ratio of direct to diffuse radiation, which impacts carbon uptake by the forest.

\section{Introduction}

Amazonia is one of the regions that is experiencing fast environmental change with important climatic implications, and it has been studied through the LBA (The Large Scale Biosphere-Atmosphere Experiment in Amazonia) experiment (Davidson et al., 2012). It is well established that tropical rainforests are critically important in the global hydrological cycle and in the global carbon budget (Davidson and Artaxo, 2004). Natural aerosols from Amazonia have been recently reviewed and indicate that in the wet season, 


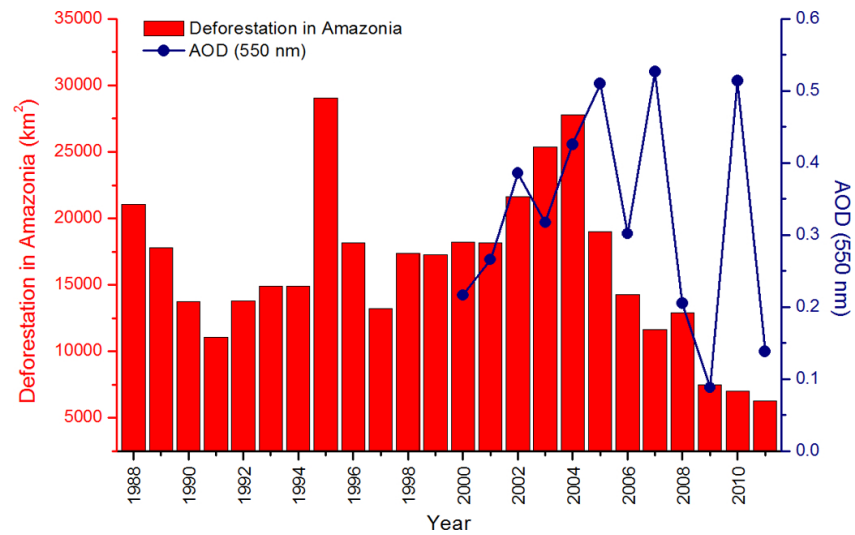

Fig. 1. Deforestation rate in Amazonia since 1988, showing the sharp decrease in Amazon deforestation since 2004 (red bars, data extracted from Prodes INPE, 2012). The blue points correspond to the mean AOD at $550 \mathrm{~nm}$, retrieved by MODIS during the biomass burning season over Amazonia. Notice that the aerosol loading does not follow the deforestation pattern. This indicates biomass burning activities aimed at the maintenance of pasture and agricultural fields.

Amazonia presents very pristine aerosol concentrations, typical of continental pre-industrial atmosphere (Martin et al., 2010a, b; Pöschl et al., 2010). Tropical emissions from biomass burning from deforestation and agricultural practices play a major role in modifying atmospheric composition, especially in the Southern Hemisphere (Bowman et al., 2009). Smoke from fires after deforestation has a large impact in convection and cloud formation, and affects the precipitation regime (Andreae et al., 2004; Koren et al., 2008). Aerosols from biomass burning have also been associated with precipitation pattern changes such as the delay in the beginning of the Amazon Basin's dry season (Bevan et al., 2009; Butt et al., 2011; Zhang et al., 2009). The accumulated deforested area over the Amazon Basin until 2011 was approximately $741000 \mathrm{~km}^{2}$ (INPE-PRODES, 2012) - larger than the whole area of France. The large area that was deforested changes the radiative budget due to surface albedo changes. However, the rate of deforestation has significantly decreased since 2004 as reported by INPE-PRODES (2012). In that year, 2004, $27000 \mathrm{~km}^{2}$ were deforested, while only $6200 \mathrm{~km}^{2}$ were deforested in 2011 (Fig. 1).

Biomass burning aerosols can affect the radiative budget directly by scattering and absorbing solar radiation (Atwater, 1970; Charlson and Pilat, 1969; Coakley Jr. et al., 1983; McCormick and Ludwig, 1967; Mitchell Jr., 1971) and indirectly by acting as cloud condensation nuclei and changing cloud properties, such as cloud albedo, lifetime and precipitation rate (Albrecht, 1989; Haywood, 2000; Forster et al., 2007; Rosenfeld and Lensky, 1998; Twomey, 1977). Land use change from forest to crops or pasture also changes the evapotranspiration rate, with consequences for the column water vapour content (Betts and Silva Dias, 2010).
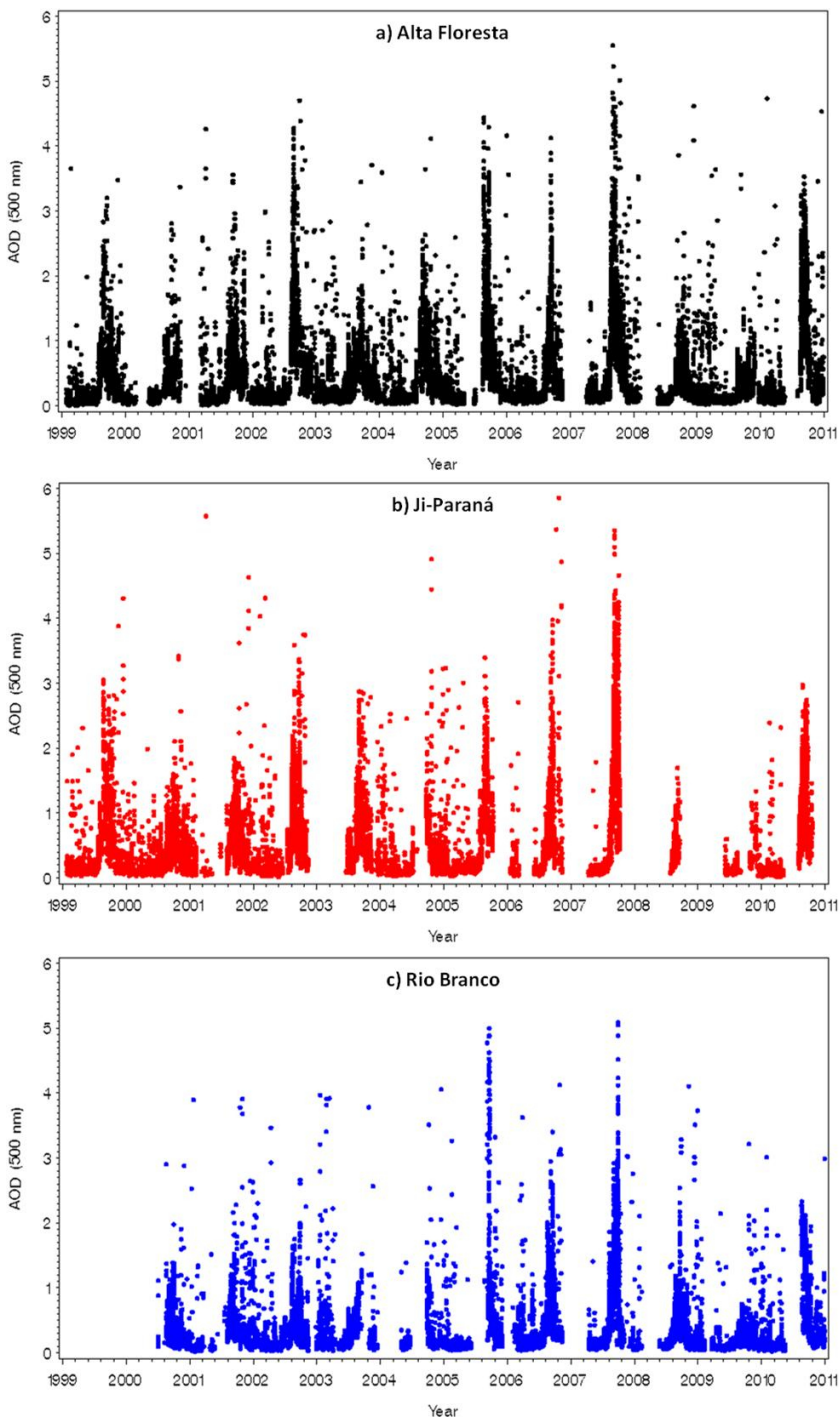

Fig. 2. Time series of aerosol optical depth (AOD) at $500 \mathrm{~nm}$ retrieved by AERONET sun-photometer for 3 places in Amazonia: (a) Alta Floresta, (b) Ji-Paraná and (c) Rio Branco. This graph illustrates the high seasonality in the aerosol loading.

Long-term aerosol monitoring in Amazonia through AERONET sunphotometers (Holben et al., 1998) shows very high aerosol optical depth (AOD) at point locations distributed widely over the region. Figure 2 shows the AOD time series for 3 sites located in the Amazon Basin. This graph illustrates the high seasonality in the aerosol loading as well as large spatial heterogeneity. Comparing the temporal pattern of deforestation and the AOD measurements (Figs. 1 and 2), it is easy to observe that, although deforestation rates have continuously decreased from 2004 on, AOD variability does not follow the same pattern. This indicates that there was a shift in biomass burning activities, initially from deforestation fires and later associated with pasture and agricultural fires (Ten Hoeve et al., 2012). The high atmospheric 
loading of biomass burning particles also has important effects on the ratio of diffuse to direct radiation (Yamasoe et al., 2006), leading to a significant increase in net ecosystem exchange (NEE), which can be enhanced by $30-40 \%$ at several observation sites in Amazonia (Oliveira et al., 2007). This increase happens when AOD at $550 \mathrm{~nm}$ increases from the background value of 0.1 to about 1.0. For further increase in AOD, the attenuation of the total solar flux starts to dominate and NEE goes to zero.

The assessment of the impacts of biomass burning aerosols in the radiation budget has previously been performed in several studies using remote sensing (e.g., Patadia et al., 2008; Christopher et al., 2000). Some of these studies analysed Clouds and the Earth's Radiant Energy System (CERES) and Moderate Resolution Imaging SpectroRadiometer (MODIS) or Multi-Angle SpectroRadiometer (MISR) AOD retrievals in order to study the effects of aerosols on the radiative budget.

The main goal of this work was to assess the temporal and spatial distributions of the shortwave direct radiative forcing at the top of the atmosphere (TOA) over the Amazon Basin due to biomass burning aerosol loading, and the effects of land use change and water vapour. A large region that includes forest, cerrado (savannah-like vegetation), pasture and cropland areas was analysed during the biomass burning season. This work was based on ten years (2000 to 2009) of CERES TOA radiative flux and MODIS aerosol optical depth cloud-free retrievals. The biomass burning aerosol forcing over areas with different surface reflectivity properties was analysed. This work also aimed to assess the radiative forcing due to changes in surface albedo caused by land use change. This is an important and frequently overlooked issue in tropical forest regions. The shortwave radiative impact of the reduction in water vapour column over deforested areas in the radiative budget was also investigated. Due to the large land use change in the tropics and high atmospheric aerosol loading from biomass burning, it is clear that biomass burning emissions, changes in surface albedo and changes in water vapour column have profound influences on the radiative balance in Amazonia. These effects could have strong implications in convection, cloud development and the ratio of direct to diffuse radiation, which impacts carbon uptake and the photosynthetic rate of the forest.

\section{Remote sensing methodology}

CERES shortwave fluxes and MODIS aerosol optical depth retrievals over the Amazon Basin obtained during the months of August and September (peak of the biomass burning season) from 2000 up to 2009 were analysed. The CERES sensor aboard the Terra satellite provides radiance measurements in the shortwave $(0.3-5.0 \mu \mathrm{m})$, infrared window $(8.0-12.0 \mu \mathrm{m})$ and total $(0.3-200 \mu \mathrm{m})$ broadband channels (Wielicki et al., 1996). As part of the CERES production line, radiances are converted to fluxes using angular dependence models (Loeb et al., 2005, 2007). The main dataset used was the CERES Single Scanner Footprint (SSF) product. In addition to the shortwave and longwave fluxes, this product also contains MODIS (MOD04) aerosol and cloud properties (Remer et al., 2005) and meteorological information computed by the Global Modelling and Assimilation Office (GMAO)'s Goddard Earth Observing System (GEOS) Data Assimilation System (DAS). MODIS aerosol data, originally available at $10 \mathrm{~km}$ spatial resolution, is translated onto CERES $20 \mathrm{~km}$ resolution by using point spread functions (Smith et al., 1994). The most recently available CERES Terra SSF Editions 2B/2F/2G-Rev1 were used in the analysis. Editions $2 \mathrm{~F}$ and $2 \mathrm{G}$ contain MOD04 collection 5 data, while edition 2B contains MOD04 collection 4 data.

Simultaneous remote sensing retrievals have been used before for the evaluation of the aerosol radiative forcing over oceans and deserts (Zhang and Christopher, 2003; Zhang et al., 2005). Patadia et al. (2008) used coincident CERES flux retrievals and MISR AOD retrievals to evaluate the direct radiative forcing of aerosols over the Amazon Basin. We opted to use MODIS's AOD contained in CERES-SSF product due to MODIS's larger swath width and consequently higher spatial coverage. MODIS's AOD uncertainty over land is reported as $\pm 0.05 \pm 0.15 \mathrm{AOD}_{550 \mathrm{~nm}}$ (Remer et al., 2005). Several studies show good agreement between AERONET and MODIS AOD globally, for both collection $4\left(\mathrm{AOD}_{\text {MODIS }}=0.1+0.9 \mathrm{AOD}_{\mathrm{AERONET}}\right)$ and collection 5 $\left(\mathrm{AOD}_{\text {MODIS }}=0.03+1.01 \mathrm{AOD}_{\mathrm{AERONET}}\right)$ data $(\mathrm{Chu}$ et al., 2002; Levy et al., 2005, 2007; Remer et al., 2005).

In this work, CERES-SSF product was used to evaluate the instantaneous direct shortwave aerosol radiative forcing (SWARF) and land use radiative forcing (LURF) due to surface albedo changes over Amazonia for a ten-year period (from 2000 to 2009), during the peak of the biomass burning season. The instantaneous forcing values were expanded to 24-h averaged values using the discrete-ordinate radiative transfer (DISORT) code (Stamnes et al., 1988). The surface and aerosol models used in the radiative transfer code were built from surface properties information provided by MODIS BRDF/Albedo Model product (Schaaf et al., 2002) and aerosol properties obtained by AERONET inversion algorithm (Dubovik and King, 2000), respectively. The methodology used in this work is summarized in Fig. 3 and will be detailed in the following sections.

\subsection{Cloud-free pixel selection}

One of the goals of this study is the assessment of the direct aerosol effect; therefore, only cloud-free satellite retrievals were used in the calculations. For that reason we used data from CERES and MODIS sensors with morning overpasses (approximately at 10:30 a.m., LT), when the region is usually less cloudy than in the afternoon. Furthermore, a pixel selection strategy was put in place based on MODIS cloud 


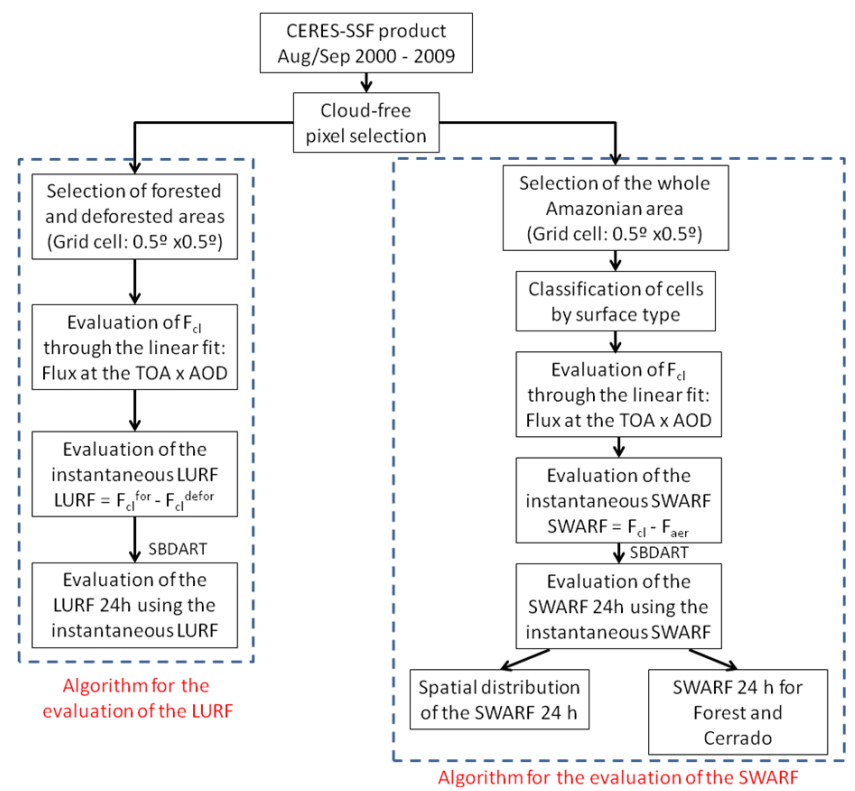

Fig. 3. Simultaneous CERES and MODIS retrievals were used for the evaluation of the mean daily shortwave aerosol radiative budget (SWARF) and of the mean daily surface albedo change radiative forcing (LURF) during the peak of the biomass burning season (August to September) from 2000 to 2009.

fraction and surface reflectance retrievals, and geometrical constraints on illumination and viewing angles. Pixels with 1 -km resolution MODIS cloud fraction above $0.5 \%$ were removed. Pixels with clear area in the MODIS $250 \mathrm{~m}$ resolution lower than $99.9 \%$ were also removed. In order to limit distortions we removed from our analysis pixels which presented view and solar zenith angles greater than $60^{\circ}$ (similarly as in Patadia et al., 2008). CERES's shortwave broadband channel $(0.3-5.0 \mu \mathrm{m})$ includes the water vapour absorption band, and thus pixels containing inland water bodies need to be removed. The assessment and removal of inland water pixels was performed using the MODIS 8-day $500 \mathrm{~m}$ resolution average surface reflectance product (Vermote and Vermeulen, 1999). CERES pixels that presented surface reflectance lower than 0.15 in the MODIS $1.2 \mu \mathrm{m}$ channel in more than $15 \%$ of their footprint were removed.

\subsection{Grid cell classification according to surface type}

In cloud-free conditions, the presence of aerosols over a surface modifies the outgoing radiation flux at the top of the atmosphere. Biomass burning aerosols from Amazonia are usually bright (single scattering albedo around 0.9 at $550 \mathrm{~nm}$ ) (Dubovik et al., 2002; Procopio et al., 2003; Schafer et al., 2008). Therefore their impact is stronger over dark surfaces (such as forest) than over brighter surfaces (such as cerrado). The influence of the different surface types that compose the studied region (forest and cerrado/croplands/pasture) on the direct radiative forcing of biomass burning aerosols was investigated.

The area under study was limited to the area between the coordinates $3^{\circ} \mathrm{N}-20^{\circ} \mathrm{S}, 45-65^{\circ} \mathrm{W}$ and $3^{\circ} \mathrm{N}-11^{\circ} \mathrm{S}, 65-$ $74^{\circ} \mathrm{W}$. After the pixel selection step this area was divided into $0.5^{\circ} \times 0.5^{\circ}$ (latitude/longitude) grid cells. The cell size was chosen so as to maximize the amount of valid pixels in each cell and to minimize surface heterogeneity. CERES provides an array of the 8 most prominent surface types and their percentage coverage within each pixel, according to the International Geosphere-Biosphere Programme (IGBP) land cover map (Loveland and Belward, 1997). Since the size of the cell needed for the SWARF evaluation is large $\left(0.5^{\circ} \times 0.5^{\circ}\right)$, and the resolution in land cover maps is much better than this, a single cell could present several different land cover types within it. Therefore it would be difficult to classify each cell as a single surface type. For that reason, each cell was classified according to the estimated broadband surface albedo from CERES. This parameter is derived by weighting the percent coverage of each surface type within the CERES field of view by the corresponding broadband surface albedo associated with that surface type. The albedo look-up tables used in this procedure are based on field observations. In this work, if the average cell broadband albedo was less than 0.140, it was classified as forest; if the average broadband albedo was greater than 0.155 , the cell was classified as cerrado; otherwise (albedo values between 0.140 and $0.155)$ the cell was classified as a transition region. Notice that the category classified as cerrado also includes croplands and pasture areas. For simplicity, however, throughout the text we will refer to high surface albedo regions simply as cerrado. The analysis of the direct radiative forcing and forcing efficiency of biomass burning aerosols over forest and cerrado/croplands/pasture areas is presented in Sect. 3.2.

\subsection{Methodology for the instantaneous aerosol direct radiative forcing calculation}

The mean shortwave aerosol radiative forcing at the TOA (SWARF) during the biomass burning season was defined as the difference between the mean radiative flux at the TOA in clean conditions $\left(F_{\mathrm{cl}}\right)$ and in polluted conditions $\left(F_{\mathrm{pol}}\right)$ observed in the studied period. In order to obtain $F_{\mathrm{cl}}$, the instantaneous shortwave radiative fluxes at the TOA observed during the satellite overpass were plotted against the AOD for each $0.5^{\circ} \times 0.5^{\circ}$ cell. For each cell, linear fits were adjusted to the data points observed for the biomass burning season of each year. It is important to emphasize that the linearity of the outgoing flux at the TOA with AOD does not hold for high AOD values. For that reason, only cases where AOD was smaller than 2 were used to perform the linear fit. The intercept of each linear fit provides the value of the shortwave radiation flux at the TOA at the limit when $\mathrm{AOD}=0$ for each grid cell. This value was assumed to be the flux at the TOA for clean conditions and used in the evaluation 
a)

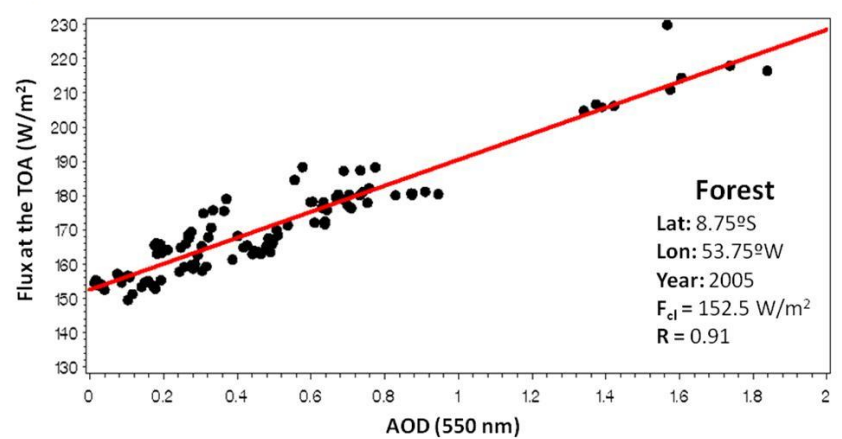

b)

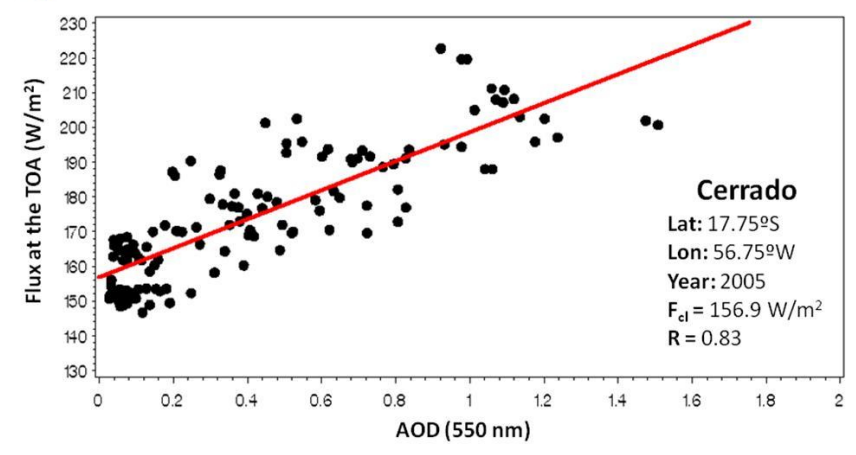

Fig. 4. Examples of the linear fit of CERES flux at the TOA versus MODIS AOD at $550 \mathrm{~nm}$ for two $0.5^{\circ} \times 0.5^{\circ}$ cells located at areas covered by (a) forest and (b) cerrado. The larger surface albedo variation within a single cell induces higher data dispersion for cerrado than for forest sites.

of the shortwave aerosol radiative forcing. Notice that by following this procedure the definition of the direct radiative forcing of aerosols used in this work considers the total effect of aerosols including the small contribution of background aerosols in Amazonia (of approximately $\mathrm{AOD}=0.1$ at $550 \mathrm{~nm}$ ). Figure 4 illustrates two examples in which the above procedure was used to evaluate the flux for clean conditions over forest and cerrado covered areas. Surface albedo is usually more homogeneous over forest than over cerrado. Therefore, surface albedo variation within a single cell induces higher data dispersion for cerrado sites as compared to forest sites.

Variations in the satellite overpass time during the months of August and September, water vapour variability, and the surface albedo heterogeneity within a single cell may introduce other sources of uncertainty besides the instrumental error of the sensor. For that reason, the uncertainties in the intercept and the slope of the regression were recalculated by setting the reduced chi-squared equal to 1 for each $0.5^{\circ} \times 0.5^{\circ}$ cell data set. To estimate the uncertainty of the SWARF, the covariance between the mean flux for clean conditions $\left(F_{\mathrm{cl}}\right)$ and the mean polluted flux $\left(F_{\mathrm{pol}}\right)$ observed during the studied period was considered. Cases with less than 10 points or with linear correlation lower than 0.2 were ex- cluded from the analysis to ensure good statistics of data in each cell. The instantaneous SWARF was expanded to a 24$\mathrm{h}$ average $\left(\mathrm{SWARF}_{24 \mathrm{~h}}\right)$ according to the procedure explained in Sect. 2.5.

The aerosol direct forcing efficiency, defined as the rate of change of the SWARF per unit increase in the AOD, was used to estimate the impact of aerosols over different surface types. In order to evaluate forest and cerrado forcing efficiencies at $550 \mathrm{~nm}$, it was assumed that the surface and aerosol optical properties remained the same during the months of August and September of each year. For this procedure, the pixels were grouped according to surface type, using the grid cell classification explained in Sect. 2.2. A linear fit of the radiative flux at the TOA by AOD was derived for each surface type, for each year. The aerosol forcing efficiencies were obtained from the slope of the linear regressions for each surface type. To ensure linearity in the fittings, the maximum AOD for each linear regression was limited to 2 . The forcing efficiency uncertainty was estimated by setting the reduced chi-squared equal to 1 .

\subsection{Methodology for the assessment of the surface albedo change radiative forcing}

In the Amazon Basin, deforestation is expected to generate a negative radiative forcing due to the increase in the surface albedo of the deforested area. Unlike the aerosol direct radiative forcing, which presents marked seasonality, deforestation likely triggers a permanent change in the radiative budget over the impacted area. In this work we quantified the shortwave land use change radiative forcing (LURF) over deforested areas in Rondônia, a region that has been deforested since the 1970s and presents a large continuous deforested area. Deforested and forested regions were selected and classified according to the visual inspection of MODIS red $(648 \mathrm{~nm})$, green $(555 \mathrm{~nm})$ and blue $(470 \mathrm{~nm})$ composite images (RGB). In order to maximize the area representing the deforested regions used in the LURF assessment, two deforested locations, D1 and D2, were selected. A forested region, F2, which has approximately the same geometrical area and is located between the same latitude ranges as the deforested areas was also selected. They also present similar characteristics concerning mean water vapour content and mean solar zenith angle during the studied period. Their locations are listed in Table 1 (LURF assessment areas) and illustrated in Fig. 5. It is worth mentioning that the deforested areas selected for the LURF assessment are not different from the crop/pasture areas contained in the cells classified as cerrado. However, for the LURF assessment we wanted to assure that the selected areas were indeed deforested, instead of savannah-like vegetation.

The selected deforested and forested areas were divided into $0.5^{\circ} \times 0.5^{\circ}$ cells. For each cell the instantaneous flux at the TOA for clean conditions $(\mathrm{AOD}=0)$ was evaluated from the intercept of the linear fit of CERES flux at the TOA 


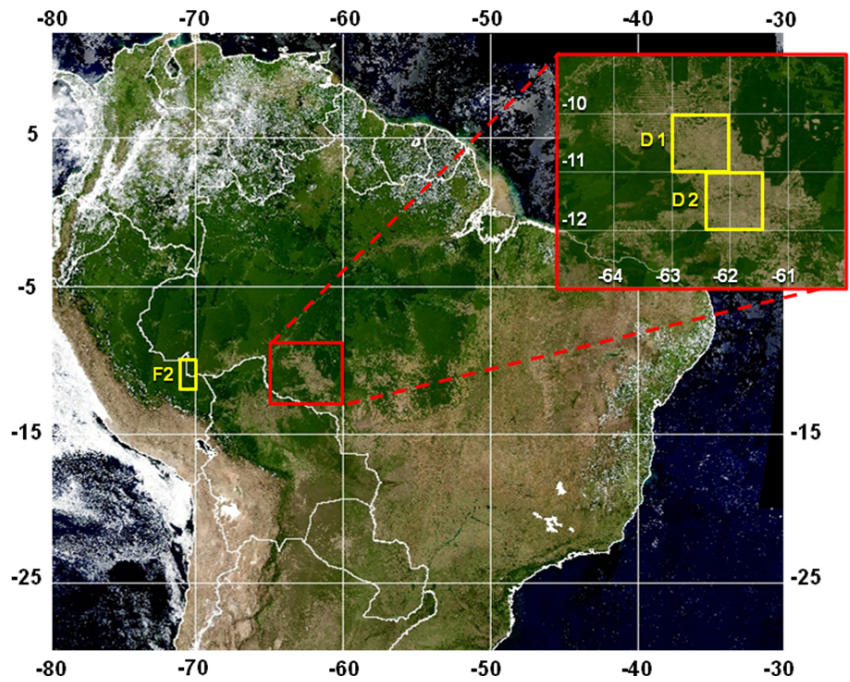

Fig. 5. Areas selected in South America for the surface albedo change radiative forcing evaluation (LURF). The yellow squares correspond to the deforested areas (D1 and D2) and forested (F2) areas selected.

by AOD. All valid data during the biomass burning seasons from 2000 to 2009 were used to evaluate the flux for clean conditions. T-Student's factor correction was applied to the uncertainty of the flux at the TOA of deforested and forested areas, due to the small number of cells in each region (only 8 valid cells). In analogy to the instantaneous SWARF, the instantaneous LURF was also expanded to a 24 -h average, as will be shown in the next section.

\subsection{Evaluation of the mean daily aerosol and surface albedo change radiative forcings}

The discrete-ordinate radiative transfer (DISORT) code SBDART (Santa Barbara DISORT Atmospheric Radiative Transfer) (Richiazzi et al., 1998) was used for the assessment of both the mean daily direct radiative forcing of aerosols $\left(\mathrm{SWARF}_{24 \mathrm{~h}}\right)$, and the mean daily surface albedo change radiative forcing due to deforestation $\left(\mathrm{LURF}_{24 \mathrm{~h}}\right)$. The methodology used to expand the instantaneous forcing values to 24-h averaged values will be detailed in the following subsections.

\subsubsection{Surface models}

The use of a radiative transfer code to evaluate the ascending flux at the TOA requires care in the choice of the simulated surface, due to the large contribution of the surface albedo for the outgoing shortwave radiative flux. In this work MODIS BRDF/Albedo Model product was used in the assessment of the spectral dependence of the albedo for forest, cerrado and deforested areas.

The solar zenith angle dependence of the directional hemispherical reflectance (black-sky albedo) and of the bihemispherical reflectance (white-sky albedo) can be param-
Table 1. Geographic locations of (i) forest (F1) and cerrado/croplands/pasture (C) regions used for the study of the effect of the surface albedo in the daily SWARF; and (ii) the deforested (D1 and D2) and forested (F2) regions selected for the LURF assessment. The surface properties of those areas were used in the SBDART radiative transfer code to obtain the 24-h SWARF and LURF cycle.

\begin{tabular}{lr}
\hline Study and area description & $\begin{array}{r}\text { Coordinates } \\
\text { (Latitude; Longitude) }\end{array}$ \\
\hline SWARF - albedo effect: Forest (F1) & $4.5-8.0^{\circ} \mathrm{S} ; 64.0-70.0^{\circ} \mathrm{W}$ \\
SWARF - albedo effect: & $10.0-18.0^{\circ} \mathrm{S} ; 46.0-48.0^{\circ} \mathrm{W}$ \\
Cerrado/Croplands/Pasture (C) & \\
LURF assessment: Deforested area 1 (D1) & $10.0-11.0^{\circ} \mathrm{S} ; 62.0-63.0^{\circ} \mathrm{W}$ \\
LURF assessment: Deforested area 2(D2) & $11.0-12.0^{\circ} \mathrm{S} ; 61.4-62.4^{\circ} \mathrm{W}$ \\
LURF assessment: Forested area (F2) & $10.0-12.0^{\circ} \mathrm{S} ; 70.0-71.0^{\circ} \mathrm{W}$ \\
\hline
\end{tabular}

eterized by polynomial functions as described by Lucht et al. (2000). The MODIS BRDF/Albedo Model product (Schaaf et al., 2002) provides the weighting parameters for the anisotropy models used to derive the black-sky and white-sky albedos at seven spectral bands $(0.470,0.555$, $0.648,0.858,1.24,1.64,2.13 \mu \mathrm{m})$. These are calculated from a combination of Terra and Aqua retrievals every 16-day overpass at a resolution of $1 \mathrm{~km}$.

Five areas were selected to build the surface models used in the radiative transfer code to represent (i) forest-covered areas (F1) and bright areas, such as cerrado (C) for the study of the impact of the surface albedo in the daily SWARF; and (ii) the deforested (D1 and D2) and forested (F2) regions used in the LURF assessment. For each area the mean white-sky and black-sky albedos as a function of the illumination geometry were obtained at 7 wavelengths, using MODIS BRDF/Albedo Model (MCD43B1) retrievals. The actual albedo (blue-sky albedo) in wavelength $\lambda\left(\alpha\left(\theta_{0}, \lambda\right)\right)$ is a linear combination of the black-sky $\left(\alpha_{\mathrm{bs}}\left(\theta_{0}, \lambda\right)\right)$ and whitesky albedo $\left(\alpha_{\mathrm{ws}}(\lambda)\right)$, according to the following equation (Lewis and Barnsley, 1994; Lucht et al., 2000; Schaaf et al., 2002):

$$
\begin{aligned}
\alpha\left(\theta_{0}, \lambda\right) & =\left[1-S\left(\theta_{0}, \tau(\lambda)\right)\right] \alpha_{\mathrm{bs}}\left(\theta_{0}, \lambda\right) \\
& +S\left(\theta_{0}, \tau(\lambda)\right) \alpha_{\mathrm{ws}}(\lambda),
\end{aligned}
$$

where $S\left(\theta_{0}, \tau(\lambda)\right)$ is the diffuse fraction of radiation that reaches the surface.

A look-up table was used to obtain the variation of $S\left(\theta_{0}, \tau(\lambda)\right)$ with the solar zenith angle $\left(\theta_{0}\right)$ and aerosol loading $(\tau(\lambda))$. The spectral dependence of the albedo was obtained by linearly interpolating the blue-sky albedo in the seven wavelengths provided by MODIS, for each $0.1 \mathrm{AOD}$ step and $1^{\circ}$ solar zenith angle step.

\subsubsection{Aerosol model}

AERONET is a federation of ground-based remote sensing aerosol network of well-calibrated sun/sky radiometers (Holben et al., 1998). AERONET inversion algorithm (Dubovik 
Table 2. Aerosol optical properties (single scattering albedo $\left(\omega_{0}\right)$, asymmetry parameter $(g)$ and extinction efficiency factor $\left(Q_{\text {ext }}\right)$ ) obtained from AERONET Lev. 2.0 aerosol inversion product used in the radiative transfer code SBDART. The numbers in parentheses represent the uncertainty in the last decimal place.

\begin{tabular}{lllll}
\hline $\begin{array}{l}\text { Wavelength } \\
(\mu \mathrm{m})\end{array}$ & 0.441 & 0.673 & 0.873 & 1.022 \\
\hline$\omega_{0}$ & $0.921(1)$ & $0.904(1)$ & $0.885(1)$ & $0.871(2)$ \\
$g$ & $0.680(1)$ & $0.577(1)$ & $0.518(1)$ & $0.491(1)$ \\
$Q_{\text {ext }}$ & $1.419(59)$ & $0.703(29)$ & $0.435(18)$ & $0.324(13)$ \\
\hline
\end{tabular}

and King, 2000) provides mean aerosol properties in the atmospheric column derived from the direct and diffuse radiation measured by AERONET sun/sky radiometers. In this work the aerosol model used as an input in the radiative transfer code was obtained from Level 2.0 (cloudscreened and quality assured) inversion data retrieved in all AERONET sites within the selected region (Alta Floresta, Abracos Hill, Ji Paraná, Rio Branco, Balbina, Belterra and Cuiabá-Miranda) from 2000-2009, during the biomassburning season (August to September). The mean values observed during the dry season for the aerosol properties (single scattering albedo $\left(\omega_{0}\right)$, asymmetry parameter $(g)$ and extinction efficiency factor $\left.\left(Q_{\text {ext }}\right)\right)$ in 4 wavelengths $(440,670,870$ and $1022 \mathrm{~nm}$ ) were used in the SBDART simulations (Table 2). These values show good agreement with other authors' previous estimates for smoke aerosol properties over Amazonia (e.g. Dubovik et al., 2002; Procopio et al., 2003; Schafer et al., 2008). The mean Angström exponent between the wavelengths 0.44 and $0.87 \mu \mathrm{m}$ observed during the period was considered in the simulations $(1.647 \pm 0.002)$. For wavelengths smaller than $440 \mathrm{~nm}$ and larger than $1022 \mathrm{~nm}$, aerosol properties were extrapolated using the mean Angström exponent obtained from AERONET measurements.

\subsubsection{SBDART simulation}

The surface and aerosol models detailed in Sects. 2.5.1 and 2.5.2 were used in SBDART to evaluate the mean daily aerosol radiative forcing $\left(\mathrm{SWARF}_{24 \mathrm{~h}}\right)$ during Amazonia's biomass burning season. The wavelength range selected for the simulations varied from 0.3 to $5.0 \mu \mathrm{m}$, corresponding to the CERES shortwave channel. The mean day of the period (day 243) and the mean column water vapour content for forest regions $(3.3 \mathrm{~cm})$ and cerrado regions $(2.1 \mathrm{~cm})$ were considered in the simulations, which were run in $0.1 \mathrm{AOD}$ steps and $1^{\circ}$ solar zenith angle steps. The solar zenith angle dependence with time for day 243 was obtained for every $2^{\circ}$ of latitude. Those functions were interpolated by 1000 points cubic splines. This procedure leads to two look-up tables: the first one relates the 24-h average aerosol radiative forcings to latitude, aerosol optical depth and surface type $\left(\operatorname{SWARF}_{24 \mathrm{~h}}^{\mathrm{SBDART}}(\tau\right.$, Lat,Surf $)$ ), and the second relates the in- stantaneous radiative forcing to solar zenith angle, AOD and surface type ( $\operatorname{SWARF}_{\text {Inst }}^{\text {SBDAT }}\left(\theta_{0}, \tau\right.$, Surf $\left.)\right)$.

For each $0.5^{\circ} \times 0.5^{\circ}$ cell, the $\mathrm{SWARF}_{24 \mathrm{~h}}$ was calculated by weighting the instantaneous SWARF obtained from CERES-SSF data by the ratio of the daily SWARF over the instantaneous SWARF obtained from SBDART simulations (Remer and Kaufman, 2006). The surface type, mean latitude, mean aerosol optical depth and mean solar zenith angle in each cell were considered for the weighting.

$$
\begin{aligned}
& \operatorname{SWARF}_{24 \mathrm{~h}}(\tau, \text { Lat, Surf })= \\
& \operatorname{SWARF}_{\text {Inst }}^{\text {CERES }}\left(\theta_{0}, \tau, \text { Surf }\right) \frac{\operatorname{SWARF}_{24 \mathrm{~h}}^{\text {SBDA }}(\tau, \text { Lat, Surf })}{\operatorname{SWARF}_{\text {Inst }}^{\text {SBDART }}\left(\theta_{0}, \tau, \text { Surf }\right)} .
\end{aligned}
$$

The weighting factor for the $\mathrm{SWARF}_{24 \mathrm{~h}}$ for transition areas was estimated by averaging the weighting factors calculated for forest and cerrado regions.

The use of Eq. (1) to expand the instantaneous aerosol forcing to a 24-h average assumes that the aerosol loading is constant throughout the day. Several studies have used AERONET measurements to show that AOD presents significant diurnal variations in Amazonia (Kaufman et al., 2000; Smirnov et al., 2002; Zhang et al., 2012). Nevertheless, some important factors have to be taken into account: (i) the diurnal variability of aerosols in Amazonia is always smaller than $15 \%$ (Zhang et al., 2012), that is, on the same order of the MODIS AOD uncertainty; (ii) during Terra overpass (around 10:30 LT) the AOD is close to the mean diurnal AOD value; (iii) the highest AOD values are observed either early in the morning or late in the afternoon, when the solar zenith angle is low, and therefore aerosols have a smaller impact on the direct radiative forcing; and (iv) the effect of lower AOD before noon will be compensated by the effect of higher AOD in the afternoon (or vice-versa). For those reasons, the impact of aerosol diurnal variability on the mean daily aerosol forcing is expected to be small.

For the evaluation of the surface albedo change radiative forcing, a procedure similar to the one above was used, considering the corresponding surface models and $\mathrm{AOD}=0$. The mean latitude of the deforested and forested areas $\left(11.00^{\circ} \mathrm{S}\right)$ and the mean column water vapour amount $(3.0 \mathrm{~cm})$ observed for the studied period were used.

\section{Results and discussions}

\subsection{Temporal and spatial distribution of the direct radiative forcing}

The mean direct radiative forcing of biomass burning aerosols and its spatial distribution were assessed over the Amazon Basin using the methodology explained in Sect. 2. Table 3 shows the results obtained for the mean and standard deviation of the AOD, instantaneous SWARF and $\mathrm{SWARF}_{24 \mathrm{~h}}$ for the studied region during the biomass burning season from 2000 to 2009. 
a)

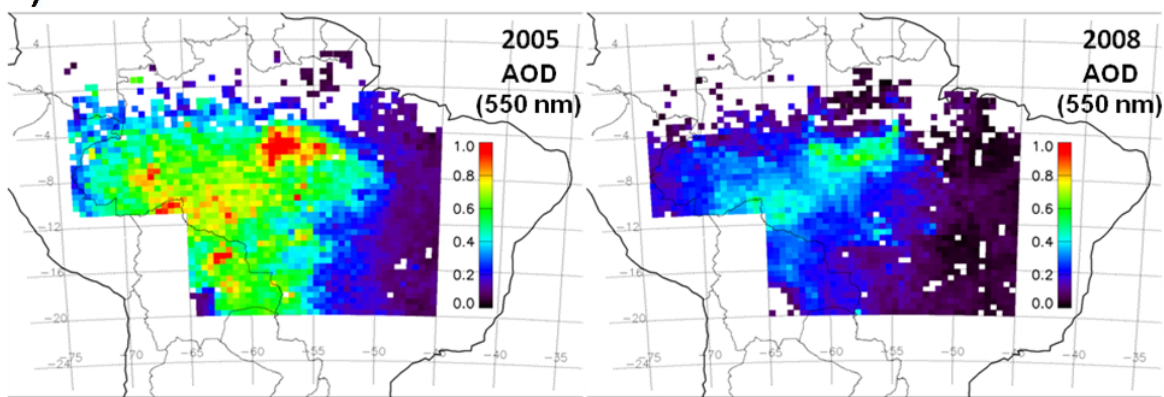

b)
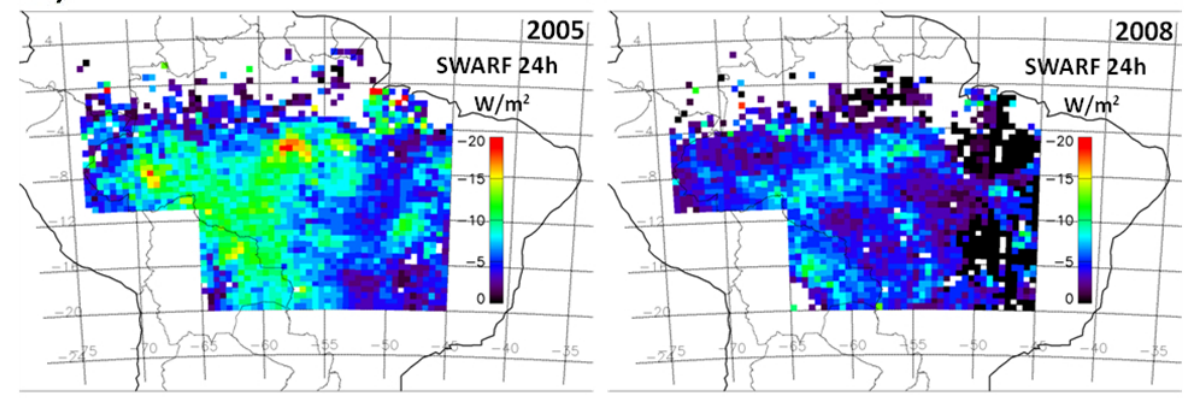

c)

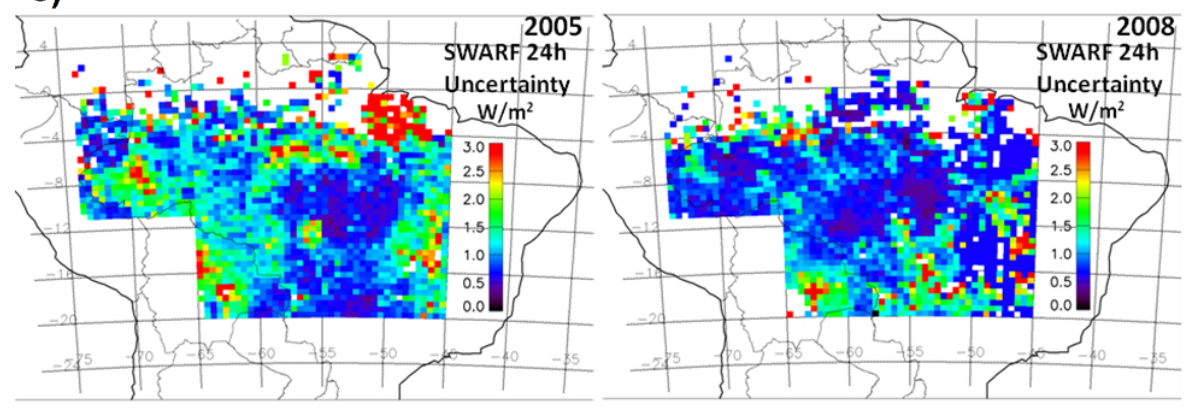

Fig. 6. Average spatial distributions during the peak of the biomass burning season of the (a) aerosol optical depth retrieved by MODIS sensor onboard Terra satellite; (b) mean daily aerosol direct radiative forcing $\left(\mathrm{SWARF}_{24 \mathrm{~h}}\right)$; and (c) estimated uncertainty of the $\mathrm{SWARF}_{24 \mathrm{~h}}$ for the years 2005 (left) and 2008 (right). To estimate the uncertainty of the SWARF $24 \mathrm{~h}$ the uncertainty of the points in each $0.5^{\circ} \times 0.5^{\circ}$ cell was estimated by setting the reduced chi-squared equal to 1 . The covariance between the flux for clean conditions $\left(F_{\mathrm{cl}}\right)$ and the mean polluted flux observed during the studied period was also considered in this calculation.

Notice that the standard deviation values shown in Table 3 represent the spatial variability of each variable and not its uncertainty. This variability is due to differences in source locations and in aerosol transport and concentration. Individually for each year, the uncertainty in the mean value of the SWARF is much smaller, approximately $10^{-1} \mathrm{~W} \mathrm{~m}^{-2}$. The year 2004 was not considered in the analysis due to the lack of valid data, caused by the high amount of MOD04 missing values for the aerosol and cloud properties in CERES-SSF database that year. The percentage of MOD04 missing values in CERES-SSF database was around $45 \%$ for 2004 , while for all the other years (2000-2003 and 2005-2009), missing values were on average only $10 \%$. The remaining 2004 pixels were located at a small area that was not representative of the entire studied area.
The results shown in Table 3 indicate that the aerosol radiative forcing at the TOA presents large spatial and temporal variations during the biomass burning season. The smaller mean SWARF values observed for the years 2008 and 2009 are due to the decrease in biomass burning emissions during those years.

The analysis of the spatial distribution of the aerosol radiative forcing allows us to assess the most and least impacted areas due to the presence of aerosol. Two examples of the spatial distribution of the AOD, $\mathrm{SWARF}_{24 \mathrm{~h}}$ and its estimated uncertainty during the months of August and September of 2005 and 2008 are given in Fig. 6.

Figure 6 shows the decrease in the absolute value of the radiative forcing at TOA in all Amazon regions from 2005 to 2008, consistent with the reduction in the average AOD 
Table 3. Mean aerosol optical depth (AOD), instantaneous shortwave aerosol radiative forcing (SWARF) and daily SWARF for the Amazon region with their respective standard deviation. These calculations were performed for the biomass burning season of the years 2000 to 2009 . The standard deviation represents the spatial variability of each parameter.

\begin{tabular}{lllll}
\hline Year & $\begin{array}{l}\text { Valid } \\
\text { Cells }\end{array}$ & $\begin{array}{l}\text { AOD } \\
(550 \mathrm{~nm})\end{array}$ & $\begin{array}{l}\text { Instantaneous } \\
\text { SWARF } \\
\left(\mathrm{W} \mathrm{m}^{-2}\right)\end{array}$ & $\begin{array}{l}\text { Daily } \\
\text { SWARF } \\
\left(\mathrm{W} \mathrm{m}^{-2}\right)\end{array}$ \\
\hline 2000 & 1163 & $0.22 \pm 0.12$ & $-12.3 \pm 6.6$ & $-7.0 \pm 3.4$ \\
2001 & 1492 & $0.18 \pm 0.08$ & $-8.1 \pm 4.1$ & $-4.7 \pm 2.3$ \\
2002 & 1447 & $0.31 \pm 0.21$ & $-12.8 \pm 7.3$ & $-6.5 \pm 3.4$ \\
2003 & 1392 & $0.25 \pm 0.14$ & $-12.0 \pm 6.5$ & $-6.4 \pm 3.0$ \\
2004 & 185 & $0.11 \pm 0.12$ & $-13.4 \pm 11.7$ & $-6.7 \pm 7.1$ \\
2005 & 1799 & $0.41 \pm 0.24$ & $-15.0 \pm 7.9$ & $-7.4 \pm 3.3$ \\
2006 & 1654 & $0.24 \pm 0.16$ & $-9.5 \pm 5.1$ & $-4.9 \pm 2.5$ \\
2007 & 1731 & $0.41 \pm 0.25$ & $-13.9 \pm 6.8$ & $-6.9 \pm 2.8$ \\
2008 & 1665 & $0.18 \pm 0.12$ & $-8.2 \pm 4.2$ & $-4.3 \pm 2.6$ \\
2009 & 1405 & $0.06 \pm 0.03$ & $-4.7 \pm 2.4$ & $-2.0 \pm 2.1$ \\
\hline Average $^{*}$ & 1528 & $0.25 \pm 0.11$ & $-10.7 \pm 3.3$ & $-5.6 \pm 1.7$ \\
\hline
\end{tabular}

* The year 2004 was excluded from the analysis due to the lack of valid data.

value observed in the period (Table 3). For regions where the aerosol loading was very high $(\mathrm{AOD}>1), \mathrm{SWARF}_{24 \mathrm{~h}}$ values as negative as $-20 \mathrm{~W} \mathrm{~m}^{-2}$ may be observed. Areas located in eastern Amazonia show a smaller radiative forcing due to the smaller concentration of aerosols over the region and also to the higher surface reflectance of those areas. In addition to the aerosol loading, other parameters such as the surface albedo, water vapour amount and solar illumination also play a role in the final radiative forcing value. These influences will be explored in the next sections.

\subsection{Surface type influence in the direct aerosol radiative forcing}

The influence of different underlying surface types on the direct radiative forcing of biomass burning aerosols from Amazonia was studied according to Sect. 2.3. The values obtained for the 24-h aerosol forcing efficiency, and the instantaneous ascending TOA flux for clean conditions for forest and cerrado, during the biomass burning seasons of the years 2000 to 2009 are listed in Table 4.

The difference of approximately $13 \mathrm{~W} \mathrm{~m}^{-2}$ between forest and cerrado instantaneous fluxes at the TOA for clean conditions is mainly due to surface albedo differences for these regions. Regions covered by forest absorb more solar radiation and therefore the upward flux at the TOA over cerrado regions is larger than over forest regions for a given illumination and viewing geometry. The values of the mean daily TOA forcing efficiency of aerosols over forest and cerrado regions are $-15.7 \pm 2.4 \mathrm{~W} \mathrm{~m}^{-2} / \tau_{550 \mathrm{~nm}}$ and $-9.3 \pm 1.7 \mathrm{~W} \mathrm{~m}^{-2} / \tau_{550 \mathrm{~nm}}$, respectively. The forcing efficiency results indicate that Amazon regions with lower sur- face albedo are subject to a more significant radiative forcing (that is, greater in modulus) than regions of brighter surface, given the same aerosol type. In other words, the impact of biomass burning aerosols in the radiative forcing is larger over forest than over cerrado, croplands or pasture. These results point out the necessity of treating forest and cerrado areas as different entities which will experience different impacts due to the presence of biomass burning aerosols.

The 24-h average aerosol forcing efficiency of the selected region as a whole, representing a significant fraction of the Amazon Basin, is $-13.1 \pm 1.6 \mathrm{~W} \mathrm{~m}^{-2} / \tau_{550 \mathrm{~nm}}$. This value was estimated by considering the analysed area as composed by $40 \%$ of savannah-like vegetation and $60 \%$ of forest vegetation.

The $\mathrm{SWARF}_{24 \mathrm{~h}}$ was also analysed separately for forest and cerrado regions (Table 5). Table 5 shows systematically more negative $\mathrm{SWARF}_{24 \mathrm{~h}}$ values for forest regions when compared to cerrado regions. The mean daily radiative forcing of biomass burning aerosols observed during the studied period was $-6.2 \pm 1.9 \mathrm{~W} \mathrm{~m}^{-2}$ over forest and $-4.6 \pm 1.6 \mathrm{~W} \mathrm{~m}^{-2}$ over cerrado. This is due to a combination of two effects: (i) the higher aerosol concentration over forest, due to the transport pattern, which brings biomass burning particles from the arc of deforestation regions to pristine forest-covered regions; and (ii) the higher aerosol impact over darker surfaces (higher AOD and higher forcing efficiency over forest regions).

\subsection{Evaluation of the surface albedo change radiative forcing over Rondônia}

The land use change radiative forcing (LURF) due to surface albedo change caused by deforestation was assessed over Rondônia following the methodology explained in Sect. 2.4. The selected deforested area (Table 1 and Fig. 5, area D1 + D2) covers approximately $20000 \mathrm{~km}^{2}$.

The values obtained for the LURF over Rondônia for the dry season from 2000 to 2009 were $-23.7 \pm 2.9 \mathrm{~W} \mathrm{~m}^{-2}$ for the instantaneous shortwave forcing and $-7.1 \pm 0.9 \mathrm{~W} \mathrm{~m}^{-2}$ for the mean daily forcing. These results show that the surface albedo change radiative forcing due to deforestation is comparable to the mean direct radiative forcing of aerosols during the biomass burning season. Nevertheless it is important to consider that emission of biomass burning aerosols is seasonal, while the impact of surface albedo change is observed during the whole year. The yearly average of the surface albedo change radiative forcing over the selected deforested area is $-7.3 \pm 0.9 \mathrm{~W} \mathrm{~m}^{-2}$. This last value was evaluated considering daily changes in the ascending solar irradiation at the TOA over the studied area. An assessment of the yearly average of the SWARF over cloudfree sky leads to a value that varies from $-0.9 \pm 0.3 \mathrm{~W} \mathrm{~m}^{-2}$ to $-1.4 \pm 0.4 \mathrm{~W} \mathrm{~m}^{-2}$, considering that the biomass burning season lasts approximately 2 to 3 months. In temperate latitudes there is a large seasonal variation in the surface albedo, 
Table 4. Mean TOA shortwave flux for no aerosols and 24-h mean aerosol forcing efficiency for forest and cerrado (savannah-like) regions with their respective uncertainties.

\begin{tabular}{|c|c|c|c|c|}
\hline \multirow[b]{2}{*}{ Year } & \multicolumn{2}{|c|}{ Forest } & \multicolumn{2}{|c|}{ Cerrado } \\
\hline & $\begin{array}{l}\text { TOA Flux for } \\
\text { AOD }=0 \\
\left(\mathrm{~W} \mathrm{~m}^{-2}\right)\end{array}$ & $\begin{array}{l}24 \mathrm{~h} \text { Forcing } \\
\text { efficiency } \\
\left(\mathrm{W} \mathrm{m}^{-2} / \tau_{550 \mathrm{~nm}}\right)\end{array}$ & $\begin{array}{l}\text { TOA Flux for } \\
\text { AOD }=0 \\
\left(\mathrm{~W} \mathrm{~m}^{-2}\right)\end{array}$ & $\begin{array}{l}24 \mathrm{~h} \text { Forcing } \\
\text { efficiency } \\
\left(\mathrm{W} \mathrm{m}^{-2} / \tau_{550 \mathrm{~nm}}\right)\end{array}$ \\
\hline 2000 & $145.76 \pm 0.09$ & $-20.20 \pm 0.12$ & $159.26 \pm 0.13$ & $-9.93 \pm 0.23$ \\
\hline 2001 & $144.41 \pm 0.06$ & $-15.08 \pm 0.10$ & $158.20 \pm 0.09$ & $-7.79 \pm 0.21$ \\
\hline 2002 & $145.26 \pm 0.07$ & $-14.17 \pm 0.06$ & $156.35 \pm 0.09$ & $-9.53 \pm 0.13$ \\
\hline 2003 & $144.39 \pm 0.07$ & $-16.18 \pm 0.07$ & $158.72 \pm 0.10$ & $-8.79 \pm 0.19$ \\
\hline 2004 & $150.11 \pm 0.73$ & $-13.60 \pm 0.47$ & $178.48 \pm 0.25$ & $-5.23 \pm 0.45$ \\
\hline 2005 & $148.48 \pm 0.07$ & $-13.75 \pm 0.05$ & $160.97 \pm 0.08$ & $-9.92 \pm 0.08$ \\
\hline 2006 & $148.18 \pm 0.05$ & $-14.89 \pm 0.05$ & $159.99 \pm 0.10$ & $-10.53 \pm 0.13$ \\
\hline 2007 & $148.03 \pm 0.06$ & $-13.48 \pm 0.04$ & $167.51 \pm 0.08$ & $-8.48 \pm 0.08$ \\
\hline 2008 & $150.87 \pm 0.06$ & $-14.64 \pm 0.08$ & $165.57 \pm 0.11$ & $-6.49 \pm 0.25$ \\
\hline 2009 & $149.96 \pm 0.06$ & $-19.28 \pm 0.22$ & $155.18 \pm 0.12$ & $-12.39 \pm 0.67$ \\
\hline Average* & $147.3 \pm 0.8$ & $-15.7 \pm 2.4$ & $160.2 \pm 1.3$ & $-9.3 \pm 1.7$ \\
\hline
\end{tabular}

* The year 2004 was excluded from the analysis due to the lack of valid data.

Table 5. Mean aerosol optical depth at $550 \mathrm{~nm}$ (AOD) and daily SWARF for forest and cerrado/croplands/pasture regions with their respective standard deviation. These calculations were performed for the biomass burning season of the years 2000 to 2009. The standard deviation represents the spatial variability of each parameter.

\begin{tabular}{llllll}
\hline & \multicolumn{2}{c}{ Forest } & & \multicolumn{2}{c}{ Cerrado/Croplands/Pasture } \\
\cline { 2 - 3 } \cline { 6 - 7 } Year & $\begin{array}{l}\text { AOD } \\
(550 \mathrm{~nm})\end{array}$ & $\begin{array}{l}\text { SWARF 24h } \\
\left(\mathrm{W} \mathrm{m}^{-2}\right)\end{array}$ & & $\begin{array}{l}\text { AOD } \\
(550 \mathrm{~nm})\end{array}$ & $\begin{array}{l}\text { SWARF 24h } \\
\left(\mathrm{W} \mathrm{m}^{-2}\right)\end{array}$ \\
\hline 2000 & $0.27 \pm 0.10$ & $-7.7 \pm 3.5$ & & $0.16 \pm 0.11$ & $-5.9 \pm 3.2$ \\
2001 & $0.21 \pm 0.07$ & $-5.0 \pm 2.4$ & & $0.12 \pm 0.07$ & $-4.3 \pm 2.3$ \\
2002 & $0.38 \pm 0.21$ & $-7.3 \pm 3.7$ & & $0.18 \pm 0.15$ & $-5.0 \pm 2.6$ \\
2003 & $0.34 \pm 0.13$ & $-7.3 \pm 3.3$ & & $0.14 \pm 0.09$ & $-5.3 \pm 2.3$ \\
2004 & - & - & & $0.10 \pm 0.11$ & $-6.0 \pm 6.1$ \\
2005 & $0.50 \pm 0.20$ & $-7.8 \pm 3.4$ & & $0.27 \pm 0.20$ & $-6.5 \pm 2.7$ \\
2006 & $0.27 \pm 0.16$ & $-5.2 \pm 2.5$ & & $0.17 \pm 0.13$ & $-4.3 \pm 2.4$ \\
2007 & $0.49 \pm 0.22$ & $-7.7 \pm 2.8$ & & $0.29 \pm 0.23$ & $-5.7 \pm 2.4$ \\
2008 & $0.24 \pm 0.11$ & $-4.9 \pm 2.3$ & & $0.09 \pm 0.07$ & $-3.4 \pm 2.8$ \\
2009 & $0.07 \pm 0.03$ & $-2.4 \pm 1.8$ & & $0.04 \pm 0.03$ & $-1.2 \pm 2.2$ \\
\hline Average* & $0.31 \pm 0.14$ & $-6.2 \pm 1.9$ & & $0.16 \pm 0.08$ & $-4.6 \pm 1.6$ \\
\hline
\end{tabular}

* The year 2004 was excluded from the analysis due to the lack of valid data.

but near the tropics the seasonal variation in surface albedo is expected to be relatively low. In order to compare the impacts of the aerosol and the land use change radiative effects over cloud-free sky, in this assessment it was assumed that the surface albedo does not change significantly during the year. Therefore the two-month period calculation was used to extrapolate the annual mean of the surface albedo change radiative forcing. This analysis indicated that, on a yearly basis, the surface albedo change radiative impact can be more than 6 times higher than the aerosol impact over the Amazon Basin for cloud-free conditions.

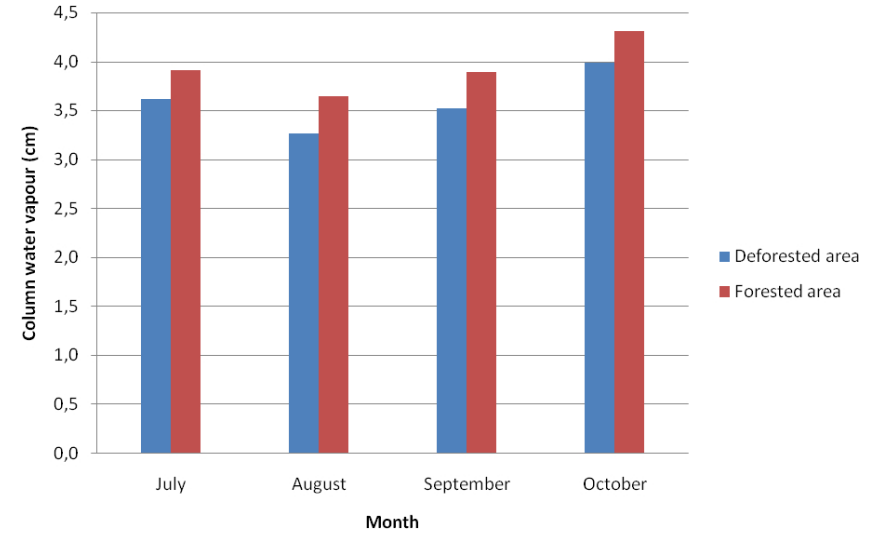

Fig. 7. Column water vapour content retrieved by AERONET sunphotometers at a deforested area (Ji Paraná - Abracos Hill, located at $10.76^{\circ} \mathrm{S}, 62.36^{\circ} \mathrm{W}$ ) and a forested area (Jaru Reserve, located at $10.08^{\circ} \mathrm{S}, 61.93^{\circ} \mathrm{W}$ ) from July to October 2002.

Deforested regions tend to be drier than forested regions, due to the smaller evapotranspiration over the area after the removal of forests. The impact of deforestation in the atmospheric water vapour content was studied over deforested (Ji Paraná - Abracos Hill) and forested (Jaru Reserve) AERONET stations. The selected sites are approximately $86 \mathrm{~km}$ apart. They are relatively close to each other and it is assumed they are subject to similar meteorological conditions. The mean difference in the water vapour amount retrieved by AERONET sunphotometers over the two stations from July to October 2002 was approximately $0.35 \mathrm{~cm}$ (Fig. 7). The behaviour of the shortwave surface albedo change radiative effect at the TOA with column water vapour content and latitude was studied. The spectral surface albedo 


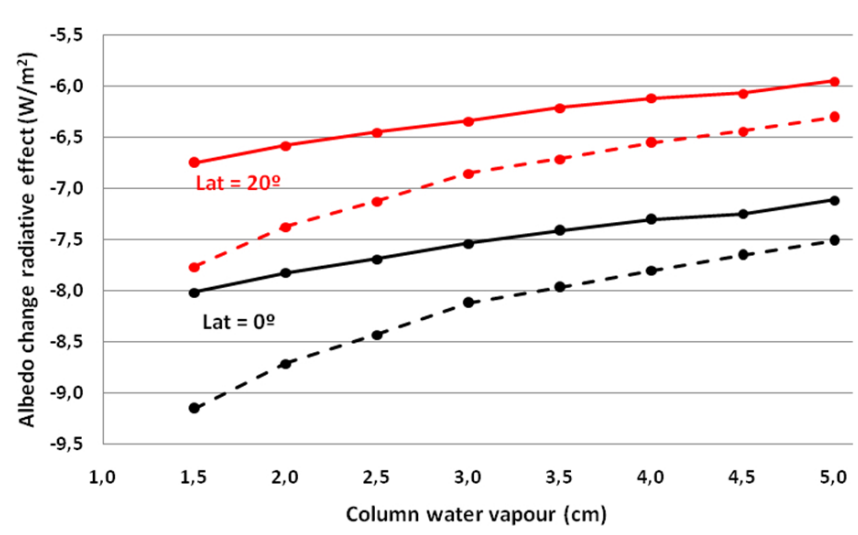

Fig. 8. Albedo change radiative effect as a function of water vapour amount in the atmosphere before deforestation. Black and red lines indicate the results over sites located at latitude $=0^{\circ}$ and at latitude $=20^{\circ}$, respectively. Solid lines represent the effect, assuming equal water amounts before and after deforestation. Dashed lines represent the effect, assuming the deforested region is $0.35 \mathrm{~cm}$ drier after deforestation.

dependence for forested and deforested regions obtained according to Sect. 2.5.1 was used as surface models in the SBDART radiative transfer code. The spectral range selected for the simulations was chosen to match CERES shortwave channel spectral range $(0.3$ to $5.0 \mu \mathrm{m})$. In the simulations, SBDART tropical atmospheric profile was used, and the total column water vapour amount was varied from 1.5 to $5.0 \mathrm{~cm}$ in $0.5 \mathrm{~cm}$ steps. Those were the typical column water vapour values observed for the studied region during the biomass burning season. Two different situations were considered for the study of the influence of water vapour in the $\mathrm{LURF}_{24 \mathrm{~h}}$ : (i) assuming that the water vapour amount is conserved after deforestation and (ii) considering that the deforested region is $0.35 \mathrm{~cm}(10 \%)$ drier after deforestation. Figure 8 shows that the surface albedo change impact is higher for situations when the amount of radiation reaching the surface is larger, that is, closer to the Equator and for lower atmospheric water vapour contents, due to gaseous absorption of infrared radiation. The surface albedo radiative forcing due to deforestation is approximately $1.2 \mathrm{~W} \mathrm{~m}^{-2}$ more negative for sites located at latitude $0^{\circ}$ than for sites located at latitude $20^{\circ} \mathrm{S}$, given the same column water vapour content for both regions.

Taking into account the drying effect, the amount of radiation reaching the surface after deforestation will be even larger due to the smaller infrared radiation absorption by water vapour. This will lead to even more pronounced radiative effects at the top of the atmosphere. Figure 8 (dashed lines) indicates that this drying impact contributes to an increase in the radiative effect, which varies from $0.4 \mathrm{~W} \mathrm{~m}^{-2}$ to $1.2 \mathrm{~W} \mathrm{~m}^{-2}$, depending on the column water vapour content before deforestation. Those results highlight the importance of considering water vapour and solar zenith angle variations when evaluating radiative effects.

\section{Discussions}

In this section we will discuss the main results presented in this work and compare them with other evaluations available in literature. The comparison between aerosol forcing efficiency results requires care, since there is not a uniform methodology in the scientific community on how to obtain this quantity. Li et al. (2000), Christopher and Zhang (2002) and Procopio et al. (2004) have calculated the forcing efficiency at wavelengths of $640 \mathrm{~nm}, 670 \mathrm{~nm}$ and $500 \mathrm{~nm}$, respectively. In order to understand the differences associated with the wavelength dependence of the forcing efficiency and to standardize it, the forcing efficiency at $550 \mathrm{~nm}$ was estimated, assuming a value of 1.647 for the Angström exponent, according to AERONET retrievals during the dry season. This normalization to $550 \mathrm{~nm}$ increases by $17 \%$ the forcing efficiency value calculated at $500 \mathrm{~nm}$, and decreases by $28 \%$ the forcing efficiency calculated at $670 \mathrm{~nm}$. This analysis illustrates the large spectral dependence of the forcing efficiency of biomass burning aerosols.

Several authors have derived only the instantaneous direct aerosol radiative forcing and/or its forcing efficiency over the Amazon Basin (e.g., Christopher et al., 2000; Christopher and Zhang, 2002; Li et al., 2000; Patadia et al., 2008). These assessments were made using retrievals from different instruments onboard satellites (e.g., GOES-8, TRMM, Terra) or using in situ aerosol optical properties measurements in radiative transfer models and assuming a given solar geometry. The problem in considering a particular illumination geometry is that the aerosol radiative forcing and forcing efficiency strongly depend on solar zenith angle. Furthermore instantaneous assessments only help us understand the aerosol impact over a given area qualitatively. For those reasons we have chosen not to compare instantaneous radiative forcing and forcing efficiencies' results. The comparison between the 24-h average results reported in this work and in previous studies is shown in Table 6.

Table 6 shows that the mean daily aerosol radiative forcing results over the Amazon Basin are compatible with other authors' work. The assessment by Patadia et al. (2008) of the direct aerosol radiative forcing was made from 2000 to 2005 , when the aerosol loading was higher than during the period considered in this work. In this work, the 24-h SWARF average from 2000 to 2005 was $-6.4 \pm 1.0 \mathrm{~W} \mathrm{~m}^{-2}$. This value is consistent with Patadia et al. (2008), who obtained $-7.6 \pm 1.9 \mathrm{~W} \mathrm{~m}^{-2}$ for the 24-h SWARF average for the same period.

The mean daily aerosol forcing efficiency values obtained for forest and cerrado regions are compatible with results reported by Ross et al. (1998). The high uncertainty observed in their results is due to the observed variability in aerosol scattering and absorption coefficients.

As pointed out in Sect. 3.3, although the mean aerosol and surface albedo change radiative forcings magnitudes are similar during the biomass burning season (Table 6), the impact 
Table 6. Comparison of the aerosol and surface radiative forcing effects with previous studies. These results were calculated during the dry season (August and September) of the period.

\begin{tabular}{llllll}
\hline Reference & Region & Period & $\begin{array}{l}24 \mathrm{~h} \\
\text { SWARF } \\
\left(\mathrm{W} \mathrm{m}^{-2}\right)\end{array}$ & $\begin{array}{l}\text { 24h Forcing } \\
\text { efficiency } \\
\left(\mathrm{W} \mathrm{m}^{-2} / \tau 550 \mathrm{~nm}\right)\end{array}$ & $\begin{array}{l}\text { 24h Albedo } \\
\text { Change RF } \\
\left(\mathrm{W} \mathrm{m}^{-2}\right)\end{array}$ \\
\hline This work & Amazon & $2000-2009$ & $-5.6 \pm 1.7$ & $-13.1 \pm 1.6$ & $-7.1 \pm 0.9$ \\
Patadia et al. (2008) & Amazon & $2000-2005$ & $-7.6 \pm 1.9$ & - & - \\
Procopio et al. (2004) & Amazon & 2002 & $-5.6 \pm 0.6^{\mathrm{a}}$ & $-10.5^{\mathrm{b}}$ & - \\
Procopio et al. (2004) & $\mathrm{AF}^{\mathrm{c}}$ & $1993-2002$ & $-8.3 \pm 2.0$ & - & - \\
Procopio et al. (2004) & $\mathrm{AH}^{\mathrm{d}}$ & $1994-2002$ & $-8.4 \pm 2.2$ & - & - \\
This work & Forest & $2000-2009$ & $-6.2 \pm 1.9$ & $-15.7 \pm 2.4$ & - \\
Ross et al. (1998) & Forest & 1995 & - & $-20 \pm 7$ & - \\
This work & Cerrado & $2000-2009$ & $-4.6 \pm 1.6$ & $-9.3 \pm 1.7$ & - \\
Ross et al. (1998) & Cerrado & 1995 & - & $-8 \pm 9$ & - \\
\hline
\end{tabular}

a This value was obtained from the mean $\mathrm{SWARF}_{24 \mathrm{~h}}$ and its standard deviation for the months August and September of 2002.

$\mathrm{b}$ The aerosol forcing efficiency was normalized for AOD at $550 \mathrm{~nm}$ using an Angström exponent value of 1.647.

${ }^{c}$ AF: Alta Floresta AERONET site.

d AH: Abracos Hill (Ji Paraná) AERONET site.

of biomass burning aerosols is seasonal, while the impact of land use change may be observed throughout the year. This difference indicates that the yearly local impact of surface albedo change in the radiative balance is more than 6 times higher than direct impact of aerosols.

\section{Summary and conclusions}

This work focused on quantifying the impact of aerosol emissions and surface albedo change on the shortwave radiation balance over the Amazon Basin in cloud-free conditions. CERES and MODIS retrievals were used to assess the temporal and spatial distributions of the direct radiative forcing of biomass burning aerosols over the Amazon Basin and the surface albedo change radiative forcing over Rondônia, both caused by deforestation. AERONET and MODIS BRDF data were used to build aerosol and surface models, respectively. These models were used in the radiative transfer code SBDART to convert instantaneous radiative forcing values into mean daily values.

The average daily direct radiative forcing of aerosols at the TOA was $-5.6 \pm 1.7 \mathrm{~W} \mathrm{~m}^{-2}$ from 2000 to 2009 during the biomass burning season (August and September). The spatial distribution analysis of the direct radiative forcing shows large geographical variability with significant impacts of aerosols over central and southwestern Amazonia. Daily averaged TOA radiative forcing values as high as $-20 \mathrm{Wm}^{-2}$ were observed for AOD higher than 1.0 at $550 \mathrm{~nm}$. Therefore, locally, the mean daily direct radiative forcing due to biomass burning aerosols may be 10 times larger than the radiative forcing due to greenhouse gases.

We also observed that land surface properties strongly impact the direct radiative forcing of aerosols. The assessment of the direct radiative forcing over different surface types indicates that the impact of biomass burning aerosols in the energy budget is higher over forest than over cerrado, croplands or pasture regions. The mean daily direct radiative forcing was $35 \%$ higher over forest than over cerrado during the studied period. Two factors contribute to this difference: (i) the typical transport of smoke from pasture and deforestation areas to large forest-covered areas, and (ii) the stronger aerosol forcing efficiency of biomass burning aerosols over darker regions. The mean daily forcing efficiencies of forest and cerrado (savannah-like) vegetation were $-15.7 \pm 2.4 \mathrm{~W} \mathrm{~m}^{-2} / \tau_{550 \mathrm{~nm}}$ and $-9.3 \pm 1.7 \mathrm{~W} \mathrm{~m}^{-2} / \tau_{550 \mathrm{~nm}}$, respectively.

In addition to biomass burning aerosol emissions, deforestation also impacts the radiative balance by changing the surface albedo of the deforested area. This modification may alter convection processes, cloud formation and the precipitation regime over the area. A value of $-7.3 \pm 0.9 \mathrm{~W} \mathrm{~m}^{-2}$ was estimated for the mean annual albedo-change radiative forcing over Rondônia. The mean annual direct radiative forcing of biomass burning aerosols was estimated at $-0.9 \pm 0.3 \mathrm{~W} \mathrm{~m}^{-2}$ over cloud-free skies, considering that the biomass burning season lasts approximately two months. This indicates that the long-term impact of surface albedo in the radiative balance is almost one order of magnitude larger than the impact of biomass burning aerosols. Those results reveal the large impact of land use change from deforestation over Amazonia's energy budget.

Deforestation also contributes to the decrease of the water vapour amount over the deforested region. The impact of deforestation in the water vapour content was assessed using AERONET column water vapour measurements over deforested and forested areas nearby. The analysed deforested area was $0.35 \mathrm{~cm}$ drier than the forested area. This decrease in the atmospheric water vapour content further enhances the effect of deforestation in the radiative balance. 
This is the first work to report the combined impact of biomass burning aerosols, changes in the surface albedo and water vapour in the shortwave radiative budget over Amazonia, in cloud-free conditions. The much higher annual average of the surface albedo change radiative forcing as compared to the direct aerosol radiative forcing draws attention to the overpowering effect of land use change over biomass burning emissions. As aerosols also change the direct to diffuse radiation ratio, and trees are quite sensitive to the increase in diffuse radiation (Oliveira et al., 2007), showing large increases in NEE (Net Ecosystem Exchange), this work is also relevant for Amazonia's carbon budget. Another important issue is the implication of our findings on the convection and cloud dynamics. Convection in Amazonia is critically important for the development of deep clouds that also have important impacts on the radiation balance and redistribution of energy in the atmosphere. The next steps would be to perform a joint analysis of the cloud-free radiative balance done in this work taking into account the key role that cloud cover changes have in the Amazonian radiative balance. Biomass burning aerosols suppress cloud formation and have an important impact on precipitation rates. It is also important to emphasize that our study is not particular to Amazonia - similar processes are also observed in Africa, Southeast Asia and other regions where large deforestation rates are observed close to primary forest areas.

Acknowledgements. The authors would like to thank Lorraine Remer, José Vanderlei Martins and Joel Brito for the helpful suggestions and for the revision of the manuscript of this paper. We also thank FAPESP (Projects 2009/08442-7, 2008/58100-2 and 2010/15959-3) and CNPq (INCT Global Change) for the financial support. CERES-SSF data were obtained from the Atmospheric Science Data Center at the NASA Langley Research Center. We thank INPA (The Brazilian National Institute for Research in Amazonia) for LBA support.

Edited by: J. Pongratz

\section{References}

Albrecht, B. A.: Aerosols, cloud microphysics, and fractional cloudiness, Science, 245, 1227-1230, 1989.

Andreae, M. O., Rosenfeld, D., Artaxo P., Costa, A. A., Frank, G. P., Longo, K. M., and Silva-Dias, M. A. F.: Smoking rain clouds over the Amazon, Science, 303, 1337-1342, 2004.

Atwater, M. A.: Planetary albedo changes due to aerosols, Science, 170, 64-66, 1970.

Betts, A. K. and Silva Dias, M. A. F.: Progress in understanding land-surface-atmosphere coupling from LBA research, Journal of Advances in Modeling Earth Systems, 2, 20 pp., doi:10.3894/JAMES.2010.2.6, 2010.

Bevan, S. L., North, P. R. J., Grey, W. M. F., Los, S. O., and Plummer, S. E.: Impact of atmospheric aerosol from biomass burning on Amazon dry-season drought, J. Geophys. Res., 114, D09204, doi:10.1029/2008JD011112, 2009.
Bowman, D. M. J. S., Balch, J. K., Artaxo, P., Bond, W. J., Carlson, J. M., Cochrane, M. A, D’Antonio, C. M., Defries, R. S., Doyle, J. C., Harrison, S. P., Johnston, F. H., Keeley, J. E., Krawchuk, M. A., Kull, C. A., Marston, J. B., Moritz, M. A., Prentice, I. C., Roos, C. I., Scott, A. C., Swetnam, T. W., Van der Werf, G. R., and Pyne, S. J.: Fire in the Earth system, Science, 324, 481-484, doi:10.1126/science.1163886, 2009.

Butt, N., de Oliveira, P. A., and Costa, M. H.: Evidence that deforestation affects the onset of the rainy season in Rondonia, Brazil, J. Geophys. Res., 116, 2-9, doi:10.1029/2010JD015174, 2011.

Charlson, R. J. and Pilat, M. J.: Climate: The in?uence of aerosols, J. Appl. Meteorol., 8, 1001-1002, 1969.

Christopher, S. A. and Zhang, J.: Daytime Variation of Shortwave Direct Radiative Forcing of Biomass Burning Aerosols from GOES-8 Imager, J. Atmos. Sci., 59, 681-691, doi:10.1175/15200469(2002)059<0681:DVOSDR>2.0.CO;2, 2002.

Christopher, S. A., Li, X., Welch, R. M., Reid, J. S., Hobbs, P. V., Eck, T. F., and Holben, B.: Estimation of surface and topof-atmosphere shortwave irradiance in biomass-burning regions during SCAR-B, J. Appl. Meteorol., 39, 1742-1753, 2000.

Chu, D. A., Kaufman, Y. J., Ichoku, C., Remer, L. A., Tanre, D., and Holben, B. N.: Validation of MODIS aerosol optical depth retrieval over land, Geophys. Res. Lett., 29, 4-7, 2002.

Coakley Jr., J. A., Cess, R. D., and Yurevich, F. B.: The effect of tropospheric aerosols on the earth's radiation budget: A parameterization for climate models, J. Atmos. Sci., 40, 116-138, 1983.

Davidson, E. A. and Artaxo, P.: Globally significant changes in biological processes of the Amazon Basin: Results of the Largescale Biosphere-Atmosphere Experiment, Global Change Biol., 10, 519-529, doi:10.1111/j.1529-8817.2003.00779.x, 2004.

Davidson, E. A., Araújo, A. C., Artaxo, P., Balch, J. K., Brown, I. F., Bustamante, M. M. C., Coe, M. T., DeFries, R. S., Keller, M., Longo, M., Munger, W., Schroeder, W., Soarez-Filho, B. S., Souza, C. M., and Wofsy, S. C.: The Amazon Basin in Transition, Nature, 481, 321-328, doi:10.1038/nature10717, 2012.

Dubovik, O. and King, M. D.: A flexible inversion algorithm for retrieval of aerosol optical properties from Sun and sky radiance measurements, J. Geophys. Res., 105, 20673-20696, doi:10.1029/2000JD900282, 2000.

Dubovik, O., Holben, B., Eck, T., Smirnov, A., Kaufman, Y., King, M., Tanré, D., and Slutsker, I.: Variability of absorption and optical properties of key aerosol types observed in worldwide locations, J. Atmos. Sci., 59, 590-608, 2002.

Forster, P., Ramaswamy, V., Artaxo, P., Berntsen, T., Betts, R. A., Fahey, D. W., Haywood, J., Lean, J., Lowe, D. C., Myhre, G., Nganga, J., Prinn, R., Raga, G., Schulz, M., and Van Dorland, R.: Changes in Atmospheric Constituents and Radiative Forcing. Chapter 2 of the Climate Change 2007: The Physical Science Basis, IPCC - Intergovernmental Panel on Climate Change Book, Cambridge University Press, United Kingdom, ISSN 978-0-52188009-1, 2007.

Haywood, J.: Estimates of the direct and indirect radiative forcing due to tropospheric aerosols: A review, Rev. Geophys., 38, 513543, doi:10.1029/1999RG000078, 2000.

Holben, B.: AERONET - A Federated Instrument Network and Data Archive for Aerosol Characterization, Remote Sens. Environ., 66, 1-16, doi:10.1016/S0034-4257(98)00031-5, 1998.

INPE-PRODES: Instituto Nacional de Pesquisas Espaciais: Projeto Prodes Monitoramento da Floresta Amazônica Brasileira por 
Satélite (http://www.obt.inpe.br/prodes), 2012.

Kaufman, Y. J., Holben, B. N., Tanré, D., Slutsker, I., Smirnov, A., and Eck, T. F.: Will aerosol measurements from Terra and Aqua polar orbiting satellites represent the daily aerosol abundance and properties?, Geophys. Res. Lett., 27, 3861-3864, 2000.

Koren, I., Martins, J. V., Remer, L. A., and Afargan, H.: Smoke invigoration versus inhibition of clouds over the Amazon, Science, 321, 946-949, 2008.

Levy, R. C., Remer, L. A., Martins, J. V., Kaufman, Y. J., Plana-Fattori, A., Redemann, J., and Wenny, B.: Evaluation of the MODIS Aerosol Retrievals over Ocean and Land during CLAMS, J. Atmos. Sci., 35, 675-992, 2005.

Levy, R. C., Remer, L. A., Mattoo, S., Vermote, E. F., and Kaufman, Y. J.: Second-generation operational algorithm: Retrieval of aerosol properties over land from inversion of Moderate Resolution Imaging Spectroradiometer spectral reflectance, J. Geophys. Res., 112, 1-21, doi:10.1029/2006JD007811, 2007.

Lewis, P. and Barnsley, M. J.: Influence of the sky radiance distribution on various formulations of the earth surface albedo, Proc. Conf. Phys. Meas. Sign. Remote Sen., Val d'Isere, France, 707715, 1994.

Li, X., Christopher, S. A, Chou, J., and Welch, R. M.: Estimation of Shortwave Direct Radiative Forcing of Biomass-Burning Aerosols Using New Angular Models, J. Appl. Meteorol., 39, 2278-2291, doi:110.1175/15200450(2001)040<2278:EOSDRF>2.0.CO;2, 2000.

Loeb, N. G., Kato, S., Loukachine, K., and Manalo-Smith, N.: Angular Distribution Models for Top-of-Atmosphere Radiative Flux Estimation from the Clouds and the Earth's Radiant Energy System Instrument on the Terra Satellite. Part I: Methodology, J. Atmos. Ocean. Tech., 22, 338-351, doi:10.1175/JTECH1712.1, 2005.

Loeb, N. G., Kato, S., Loukachine, K., Manalo-Smith, N., and Doelling, D. R.: Angular Distribution Models for Top-ofAtmosphere Radiative Flux Estimation from the Clouds and the Earth's Radiant Energy System Instrument on the Terra Satellite. Part II: Validation, J. Atmos. Ocean. Tech., 24, 564-584, doi:10.1175/JTECH1983.1, 2007.

Loveland, T. R. and Belward, A. S.: The IGBP-DIS global $1 \mathrm{~km}$ land cover data set, DISCover: First results, Int. J. Remote Sens., 18, 3289-3295, doi:10.1080/014311697217099, 1997.

Lucht, W., Schaaf, C. B., and Strahler, A. H.: An algorithm for the retrieval of albedo from space using semiempirical BRDF models, IEEE T. Geosci. Remote Sens., 38, 977-998, doi:10.1109/36.841980, 2000.

Martin, S. T., Andreae, M. O., Althausen, D., Artaxo, P., Baars, H., Borrmann, S., Chen, Q., Farmer, D. K., Guenther, A., Gunthe, S. S., Jimenez, J. L., Karl, T., Longo, K., Manzi, A., Müller, T., Pauliquevis, T., Petters, M. D., Prenni, A. J., Pöschl, U., Rizzo, L. V., Schneider, J., Smith, J. N., Swietlicki, E., Tota, J., Wang, J., Wiedensohler, A., and Zorn, S. R.: An overview of the Amazonian Aerosol Characterization Experiment 2008 (AMAZE08), Atmos. Chem. Phys., 10, 11415-11438, doi:10.5194/acp-1011415-2010, 2010a.

Martin, S. T., Andreae, M. O., Artaxo, P., Baumgardner, D., Chen, Q., Goldstein, A. H., Guenther, A. B., Heald, C. L., MayolBracero, O. L., McMurry, P. H., Pauliquevis, T., Pöschl, U., Prather, K. A., Roberts, G. C., Saleska, S. R., Silva Dias, M. A., Spracklen, D. V., Swietlicki, E., and Trebs, I.: Sources and
Properties of Amazonian Aerosol Particles, Rev. Geophys., 48, RG2002, doi:10.1029/2008RG000280, 2010b.

McCormick, R. A. and Ludwig, J. H.: Climate modification by atmospheric aerosols, Science, 156, 1358-1359, 1967.

Mitchell Jr., J. M.: The effect of atmospheric aerosols on climate with special reference to temperature near the Earth's surface, J. Appl. Meteorol., 10, 703-714, 1971.

Oliveira, P. H. F., Artaxo, P., Pires Jr., C., Lucca, S., Procópio, A., Holben, B., Schafer, J., Cardoso, L. F., Wofsy, S. C., and Rocha, H. R.: The effects of biomass burning aerosols and clouds on the $\mathrm{CO}_{2}$ flux in Amazonia, Tellus B, 59B, 338-349, doi:10.1111/j.1600-0889.2007.00270.x, 2007.

Patadia, F., Gupta, P., Christopher, S. A., and Reid, J. S.: A multisensor satellite-based assessment of biomass burning aerosol radiative impact over Amazonia, J. Geophys. Res., 113, D12214, doi:10.1029/2007JD009486, 2008.

Procopio, A. S., Remer, L. A., Artaxo, P., Kaufman, Y., and Holben, B. N.: Modeled spectral optical properties for smoke aerosols in Amazonia, Geophys. Res. Lett., 30, 2265-2270, doi:10.1029/2003GL018063, 2003.

Procopio, A., Artaxo, P., Kaufman, Y., Remer, L., Schafer, J., and Holben, B.: Multiyear analysis of Amazonian biomass burning smoke radiative forcing of climate, Geophys. Res. Lett, 31, L03108-L03112, doi:10.1029/2003GL018646, 2004.

Pöschl, U., Martin, S. T., Sinha, B., Chen, Q., Gunthe, S. S., Huffman, J. A., Borrmann, S., Farmer, D. K., Garland, R. M., Helas, G., Jimenez, J. L., King, S. M., Manzi, A., Mikhailov, E., Pauliquevis, T., Petters, M. D., Prenni, A. J., Roldin, P., Rose, D., Schneider, J., Su, H., Zorn, S. R., Artaxo, P., and Andreae, M. O.: Rainforest aerosols as biogenic nuclei of clouds and precipitation in the Amazon, Science, 329, 1513-1516, doi:10.1126/science.1191056, 2010.

Remer, L. A. and Kaufman, Y. J.: Aerosol direct radiative effect at the top of the atmosphere over cloud free ocean derived from four years of MODIS data, Atmos. Chem. Phys., 6, 237-253, doi:10.5194/acp-6-237-2006, 2006.

Remer, L. A., Kaufman, Y. J., Tanré, D., Mattoo, S., Chu, D. A., Martins, J. V., Li, R. R., Ichoku, C., Levy, R. C., Kleidman, R. G., Eck, T. F., Vermote, E., and Holben, B. N.: The MODIS aerosol algorithm, products and validation, J. Atmos. Sci., 62, 947-973, 2005.

Ricchiazzi, P., Yang, S., Gautier, C., and Sowle, D.: SBDART: A Research and Teaching Software Tool for Plane-Parallel Radiative Transfer in the Earth's Atmosphere, B. Am. Meteorol. Soc., 79, 2101-2114, 1998.

Rosenfeld, D. and Lensky, I. M.: Satellite-based insights into precipitation formation processes in continental and maritime convective clouds, B. Am. Meteorol. Soc., 79, 2457-2476, 1998.

Ross, J., Hobbs, P., and Holben B.: Radiative characteristics of regional hazes dominated by smoke from biomass burning in Brazil: Closure tests and direct radiative forcing, J. Geophys. Res., 103, 31925-31941, 1998.

Schaaf, C. B., Gao, F., Strahler, A. H., Lucht, W., Li, X., Tsang, T., Strugnell, N. C., Zhang, X., Jin, Y., Muller, J.-P., Lewis, P., Barnsley, M., Hobson, P., Disney, M., Dunderdale, M., Doll, C., d'Entremont, R. P., Hu, B., Liang, S., Privette, J. L., and Roy, D.: First operational BRDF, albedo nadir reflectance products from MODIS, Remote Sens. Environ., 83, 135-148, doi:10.1016/S0034-4257(02)00091-3, 2002. 
Schafer, J. S., Eck, T. F., Holben, B. N., Artaxo, P., and Duarte, A.: Characterization of the optical properties of atmospheric aerosols in Amazonia from long term AERONET monitoring (1993-1995; 1999-2006), J. Geophys. Res.-Atmos., 113, D04204, doi:10.1029/2007JD009319, 2008.

Smirnov, A., Holben, B. N., Eck, T. F., Slutsker, I., Chatenet, B., and Pinker, R. T.: Diurnal variability of aerosol optical depth observed at AERONET (Aerosol Robotic Network) sites, Geophys. Res. Lett., 29, 28-31, doi:10.1029/2002GL016305, 2002.

Smith, G. L.: Effects of time response on the point spread function of a scanning radiometer, Appl. Opt., 33, 7031-7037, 1994.

Stamnes, K., Tsay, S. C., Wiscombe, W., and Jayaweera, K.: Numerically stable algorithm for discrete-ordinate-method radiative transfer in multiple scattering and emitting layered media, Appl. Opt., 27, 2502-2509, 1988.

Ten Hoeve, J. E., Remer, L. A., Correia, A. L., and Jacobson, M. Z.: Recent shift from forest to savanna burning in the Amazon Basin observed by satellite, Environ. Res. Lett., 7, 024020, doi:10.1088/1748-9326/7/2/024020, 2012.

Twomey, S.: The influence of pollution on the shortwave albedo of clouds, J. Atmos. Sci., 34, 1149-1152, 1977.

Vermote, E. F. and Vermeulen, A.: Atmospheric correction algorithm: Spectral reflectance (MOD09), MODIS algorithm technical background document, version 4.0, University of Maryland, Department of Geography, 1999.

Wielicki, B. A., Barkstrom, B. R., Harrison, E. F., Lee, R. B., Smith, G. L., and Cooper, J. E.: Clouds and the Earth's Radiant Energy System (CERES): An Earth observing system experiment, B. Am. Meteorol. Soc., 77, 853-868, 1996.
Yamasoe, M. A., von Randow, C., Manzi, A. O., Schafer, J. S., Eck, T. F., and Holben, B. N.: Effect of smoke and clouds on the transmissivity of photosynthetically active radiation inside the canopy, Atmos. Chem. Phys., 6, 1645-1656, doi:10.5194/acp-61645-2006, 2006.

Zhang, J. and Christopher, S. A.: Longwave radiative forcing of Saharan dust aerosols estimated from MODIS, MISR, and CERES observations on Terra, Geophys. Res. Lett., 30, 2188, doi:10.1029/2003GL018479, 2003.

Zhang, J., Christopher, S. A., and Remer, L.: Shortwave aerosol radiative forcing over cloud-free oceans from Terra: 2. Seasonal and global distributions, J. Geophys. Res, 110, D10S24, doi:10.1029/2004JD005009, 2005.

Zhang, Y., Fu, R., Yu, H., Qian, Y., Dickinson, R., Silva Dias, M. A. F., da Silva Dias, P. L., and Fernandes, K.: Impact of biomass burning aerosol on the monsoon circulation transition over Amazonia, Geophys. Res. Lett., 36, L10814, doi:10.1029/2009GL037180, 2009.

Zhang, Y., Yu, H., Eck, T. F., Smirnov, A., Chin, M., Remer, L. A., Bian, H., Tan, Q., Levy, R., Holben, B. N., and Piazzolla, S.: Aerosol daytime variations over North and South America derived from multiyear AERONET measurements, J. Geophys. Res., 117, 1-13, doi:10.1029/2011JD017242, 2012. 